\title{
KREDIBILITAS BANK SENTRAL DAN PERSISTENSI INFLASI DI INDONESIA
}

\author{
Rachman Hakim \\ hakim_rachman@ymail.com \\ Universitas Madura \\ Munawar Ismail \\ Arif Hoetoro \\ Universitas Brawijaya Malang
}

\begin{abstract}
The relationship between the credibility of the central bank and the persistence of inflation is still ambigous as this information is crucial in setting the appropriate policy for combating an inflation problem. The objective of this paper is to measure the rate of inflation persistence and to examine the importance of the credibility of the bank central on the persistence of inflation in Indonesia by using the New Keynesian Phillips Curve Hybrid. It is found that the persistence of inflation in the period of full - fledged Inflation Targeting (2006:1-2012:3) lower when compared with the period of Inflation Targeting Lite (2000:1-2005:4). Meanwhile, the credibility of the central bank is significantly influencing the persistence of inflation only when Indonesia was implementing the FullFledged Inflation Targeting. When Indonesia was applying the Inflation Targeting Lite, the impact of bank central credibility on persitence inflation was not significant. These findings indicate that the behavior of inflation in Indonesia was backward looking during the periode of Inflation Targeting Lite and becoming forwardlooking after adopting the Full-Fledged Inflation Targeting Policy. This change is related to the increased credibility of the central bank in the full - fledged Inflation Targeting period.
\end{abstract}

Keywords: credibility, persistence ofinflation

\begin{abstract}
ABSTRAK
Hubungan kredibilitas bank sentral dan persistensi inflasi masih menjadi kontroversi, padahal kepastian hubungan ini sangat penting untuk merumuskan kebijakan anti inflasi yang tepat. Tujuan penelitian ini adalah untuk mengukur tingkat persistensi inflasi dan menguji dampak kredibilitas bank sentral terhadap persistensi inflasi di Indonesia sejak penerapan inflation targeting framework dengan menggunakan model New Keynesian Phillips Curve Hybrid. Hasil penelitian menunjukkan bahwa persistensi inflasi pada periode Full-Fledged Inflation Targeting (2006:1-2012:3) lebih rendah jika dibandingkan dengan periode Inflation Targeting Lite (2000:1-2005:4). Sementara itu, kredibilitas bank sentral berpengaruh secara signifikan terhadap persistensi inflasi pada saat Indonesia menerapkan FullFledged Inflation Targeting, sedangkan pada saat Indonesia masih menerapkan Inflation Targeting Lite, kredibilitas bank sentral tidak berpengaruh terhadap persistensi inflasi. Ini menunjukkan bahwa perilaku inflasi di Indonesia masih bersifat backward looking pada masa penerapan Inflation Targeting Lite dan berubah menjadi forward looking setelah mengadopsi Full-Fledged Inflation Targeting. Perubahan ini ada kaitannya dengan meningkatnya kredibilitas bank sentral pada periode Full-Fledged Inflation Targeting.
\end{abstract}

Kata Kunci: Kredibilitas, persistensi inflasi

\section{PENDAHULUAN}

Krisis moneter yang melanda Indonesia tahun 1997/1998 menuntut Bank Indonesia untuk mengubah tatanan kelembagaan menjadi bank sentral yang lebih independen. Perubahan ini didasari munculnya banyak pendapat yang mengatakan bahwa salah satu penyebab krisis adalah ketidakmampuan Bank Indonesia untuk bertindak secara objektif karena selama periode prakrisis kebijakan Bank Indonesia selalu dianggap terkait dengan kepentingan politik 
pemerintah. Perubahan tatanan ini diwujudkan dengan mengganti UndangUndang No. 13 Tahun 1968 dengan UndangUndang No. 23 Tahun 1999 tentang Bank Indonesia (Pohan, 2008).

Dengan diterapkannya Undang-Undang No. 23 Tahun 1999, Bank Indonesia memasuki sebuah era baru dalam sejarah moneter di Indonesia selain menjadi lembaga yang independen, Bank Indonesia juga mempunyai tujuan yaitu mencapai dan memelihara kestabilan nilai rupiah.

Stabilitas nilai rupiah bisa dilihat dari dua sudut pandang, yaitu nilai rupiah terhadap mata uang negara lain (kurs) dan nilai rupiah terhadap barang (inflasi), tetapi dengan menganut sistem nilai tukar mengambang, menunjukkan secara implisit bahwa tujuan kebijakan moneter di Indonesia adalah menjaga kestabilan harga (inflasi).

Sebagai implementasi dari undangundang baru tersebut, pada awal tahun 2000 Bank Indonesia mulai mengumumkan target inflasi sebagai sasaran akhir kebijakan moneter. Sejak saat itu, target inflasi menjadi elemen penting dalam kebijakan moneter, utamanya karena target tersebut diumumkan secara eksplisit kepada publik. Dengan demikian, penetapan sasaran inflasi menjadi sesuatu yang mengikat dalam setiap perumusan kebijakan moneter Bank Indonesia. Penetapan inflasi sebagai satu-satunya sasaran akhir dalam sebuah kebijakan moneter seringkali disebut dengan Inflation Targeting Framework (ITF), tetapi kerangka kebijakan moneter yang dipraktekkan Bank Indonesia berdasarkan Undang-Undang No. 23 Tahun 1999 masih dikategorikan sebagai Inflation Targeting Lite karena masih tercampur dengan komitmen untuk mencapai tujuan kebijakan yang lain (Pohan, 2008).

Setelah beberapa tahun menggunakan Undang-Undang No. 23 Tahun 1999 sebagai dasar kebijakan moneter, akhirnya diumumkan Undang-Undang No. 3 Tahun 2004 Pasal 7 sebagai sebuah landasan baru dalam membuat kebijakan moneter. Hal ini bisa dikatakan sebagai batu loncatan bagi Bank
Indonesia dari penerapan inflation targeting lite menuju full-fledged inflation targeting. Artinya, dengan dikeluarkannya UndangUndang No. 3 Tahun 2004 Pasal 7, maka Bank Indonesia bisa dibilang menganut Inflation Targeting Framework secara penuh (Harmanta et al., 2011).

Dalam kerangka ITF, Bank Indonesia mengumumkan sasaran inflasi ke depan pada periode tertentu. Setiap periode Bank Indonesia mengevaluasi apakah proyeksi inflasi ke depan masih sesuai dengan sasaran yang ditetapkan. Proyeksi ini dilakukan dengan sejumlah model dan sejumlah informasi yang dapat menggambarkan kondisi inflasi ke depan. Jika proyeksi inflasi sudah tidak kompatibel dengan sasaran, Bank Indonesia melakukan respon dengan menggunakan instrumen yang dimiliki. Misalnya jika proyeksi inflasi telah melampaui sasaran, maka Bank Indonesia akan cenderung melakukan pengetatan moneter. Akan tetapi, masalahnya proyeksi inflasi bank sentral seringkali berbeda dengan ekspektasi inflasi para pelaku ekonomi.

Erceg dan Levin (2003) beranggapan bahwa pelaku ekonomi akan membentuk ekspektasi inflasi sendiri yang dapat berbeda dari yang diinginkan oleh bank sentral ketika para pelaku ekonomi hanya memiliki informasi yang terbatas baik mengenai target inflasi (jangka panjang) maupun komitmen bank sentral dalam stabilisasi inflasi. Sebaliknya, dapat pula terjadi ketika bank sentral menghadapi ketidakpastian bagaimana proses pembentukan ekspektasi para pelaku ekonomi maka menurut Aoki dan Kimura (2006) langkah stabilisasi bank sentral juga akan cenderung tidak sistematis (unsystematic monetary policy).

Dalam perjalannya ITF tidaklah menuai hasil seperti yang diharapkan. Target inflasi yang sudah ditetapkan seringkali tidak sesuai dengan inflasi aktual (Bank Indonesia, 2012). Bank Indonesia terlihat masih menemui banyak kendala untuk mengontrol laju inflasi. Hal ini tentu harus diperbaiki oleh Bank Indonesia untuk memperbaiki kredibilitas mereka di mata masyarakat 
Indonesia. Bank Indonesia harus bisa menentukan instrumen kebijakan yang tepat agar inflasi aktual berada pada kisaran yang diharapkan atau sesuai dengan target inflasi.

Inflasi aktual yang seringkali tidak sesuai dengan target inflasi bisa jadi akan mengurangi keyakinan para pelaku ekonomi tentang kredibilitas sasaran inflasi dan kerangka kerja kebijakan moneter yang ditempuh bank sentral. Akhirnya perilaku pelaku ekonomi menjadi backward looking dan inflasi cenderung menjadi lebih sulit untuk dikontrol dan tidak mudah dipengaruhi oleh kebijakan moneter secara cepat. Hal inilah yang nantinya akan menimbulkan sebuah fenomena yang kita kenal sebagai persistensi inflasi.

Secara lebih spesifik, untuk dapat merancang strategi kebijakan moneter yang tepat dalam lingkungan inflasi yang persisten diperlukan pemahaman yang mendalam mulai dari gejala persistensi inflasi itu sendiri, pengetahuan tentang mekanisme dan faktor-faktor yang mendorong munculnya fenomena persistensi inflasi, perilaku mikro yang mendominasi persistensi inflasi, pengaruh trade-off antara kestabilan harga dan promosi pertumbuhan terhadap persistensi inflasi, hingga pengaruh ketidakpastian terhadap strategi kebijakan moneter.

Penelitian mengenai persistensi inflasi pernah beberapa kali dilakukan di Indonesia. Alamsyah (2008) mengemukakan mengenai adanya persistensi inflasi yang tinggi di Indonesia, dimana persistensi inflasi disaggregat untuk kategori makanan dan jasa masing-masing 0,8 dan 0,9 , tetapi terdapat kecenderungan bahwa ada kecenderungan derajat persistensi inflasi mulai menurun dalam periode pasca krisis.

Penelitian Harmanta, Bathaluddin dan Waluyo (2011) menunjukkan bahwa persistensi inflasi di Indonesia cenderung mengalami penurunan pada full-fledged inflation targeting jika di- bandingkan dengan persistensi inflasi pada masa inflation targeting lite. Persistensi inflasi sendiri diperkirakan memiliki keterkaitan dengan kredibilitas bank sentral. Hal ini seperti yang diungkapkan dalam penelitian- nya Davis (2012) serta Gonzalez dan Hamann (2011). Turunnya persistensi inflasi di masa full-fledged inflation targeting harusnya menunjukkan bahwa kredibilitas bank sentral mengalami perbaikan pada periode tersebut, pada kenyataannya tidaklah demikian. Kredibilitas bank sentral pada masa full-fledged inflation targeting tidaklah lebih baik jika dibandingkan dengan masa inflation targeting lite, hanya satu kali bank sentral mampu mencapai target inflasi yaitu tahun 2007. Fenomena mengenai persistensi memang menarik untuk diteliti, begitu pula dengan studi tentang kredibilitas otoritas moneter di suatu negara.

Dalam konteks Indonesia yang baru tahun 2005 mencoba melaksanakan ITF secara konsisten, berbagai perkembangan dan pandangan yang ada pada dasarnya menunjukkan bahwa upaya meningkatkan kredibilitas kebijakan moneter akan mendapatkan tantangan yang tidak ringan. Kredibilitas sendiri bisa jadi memiliki pengaruh yang krusial terhadap tingkat persistensi inflasi.

Dari paparan sebelumnya sepertinya sudah menjadi pandangan umum bahwa kredibilitas Bank Indonesia sedikit diragukan sehingga berakibat pada sulitnya mengendalikan inflasi. Kurangnya kredibilitas Bank Indonesia bisa berakibat pada cenderung persistennya inflasi di Indonesia sehingga Bank Indonesia kesulitan untuk mengontrol laju inflasi (Harmanta et al., 2011). Davis (2012) meneliti apakah perubahan tingkat inflasi dan ekspektasi inflasi di Amerika Serikat sangat dipengaruhi oleh kredibilitas bank sentral. Hasil akhirnya menunjukkan bahwa perubahan level kredibilitas bank sentral sangat menentukan tingkat persistensi inflasi di Amerika Serikat.

Sargent (1999) berpendapat bahwa penurunan persistensi inflasi AS selama tahun 1990-an sangat terkait dengan peningkatan kredibilitas kebijakan moneter. Hal ini menjadi dasar bagi Gonzalez dan Hamann (2011) untuk berhipotesis bahwa 
kurangnya kredibilitas kebijakan moneter adalah sumber persistensi inflasi.

Gonzalez dan Hamann (2011) mengukur persistensi inflasi di Kolombia untuk periode 1990-2010. Mereka juga meneliti apakah kredibilitas memiliki keterkaitan dengan persistensi inflasi. Hasilnya cukup mengejut kan dimana kredibilitas memang berpengaruh terhadap persistensi inflasi tetapi pengaruhnya tidaklah terlalu besar. Pada periode penelitian, bank sentral beberapa kali mengalami penurunan kredibilitas, tetapi tingkat persistensi inflasi di Kolombia tetaplah konstan.

Berbeda dengan pendapat Davis (2012) serta Gonzalez dan Hamann (2011) mengenai pengaruh kredibilitas, Garcia (2000) dan Ghezzi (2001) terlihat masih ragu apakah kredibilitas memiliki pengaruh terhadap persistensi inflasi. Sebenarnya masalahnya lebih pada ukuran kredibilitas itu sendiri. Tidak ada aturan baku dalam pengukuran kredibilitas.

Artinya agak susah untuk mengukur kredibilitas sehingga pengaruhnya terhadap persistensi inflasi juga sulit ditentukan. Perbedaan hasil dari beberapa penelitian ini menunjukkan bahwa sebenarnya pendapat bahwa kredibilitas bank sentral berpengaruh terhadap persistensi inflasi masih menjadi sebuah kontroversi. Artinya, pendapat ini bisa benar dan bisa pula tidak. Hal inilah yang membuat penelitian mengenai pengaruh kredibilitas terhadap persistensi inflasi masih menarik untuk diteliti.

Berdasarkan uraian di atas maka rumusan masalah dari penelitian ini adalah seberapa besar tingkat persistensi inflasi di Indonesia dan apakah kredibilitas bank sentral memiliki pengaruh terhadap persistensi inflasi di Indonesia.

Tujuan penelitian ini adalah untuk melihat besarnya tingkat atau derajat persistensi inflasi di Indonesia. Selanjutnya, akan diteliti apakah kredibilitas bank sentral memiliki pengaruh terhadap persistensi inflasi di Indonesia.

\section{TINJAUAN TEORETIS \\ Kredibilitas Bank Sentral}

Giavazzi dan Pagano (1988) mendefinisikan kredibilitas sebagai ukuran mengenai bagaimana pembuat kebijakan bisa mempengaruhi kejadian-kejadian di masa mendatang dengan memberikan pengumuman mengenai kebijakan yang akan dilakukan saat ini.

Bank sentral yang bisa mempengaruhi ekspektasi inflasi akan mendapat kebijakan moneter yang efektif karena kebijakan moneternya bisa dipercaya. Beberapa penelitian mengindikasikan bahwa masalah kredibilitas kebijakan moneter bisa muncul karena pelaku ekonomi dihadapkan pada ketidakpastian mengenai pilihan kebijakan dari otoritas moneter.

Blinder mendefinisikan kredibilitas sebagai 'perbuatan yang sesuai dengan perkataan (Harmanta et al., 2011). Kompatibilitas antara kata dan tindakan adalah apa yang sebenarnya menjadi inti dari kredibilitas. Sebuah bank sentral dianggap kredibel jika mereka benar-benar menjalankan kebijakan moneter untuk mencapai sasaran yang telah ditetapkan. Definisi yang hampir mirip dengan Svensson (1999) yang menunjukkan bahwa kebijakan moneter yang kredibel tercermin dalam hubungan dekat antara target inflasi dengan ekspektasi pelaku ekonomi.

Agenor dan Taylor (1993) pernah melakukan penelitian mengenai efek kredibilitas dalam konteks kebijakan stabilisasi di negara-negara yang tinggi tingkat inflasinya. Sebuah prosedur alternatif dengan memasukkan variabel kredibilitas secara eksplisit dalam model regresi. Agenor dan Taylor menyatakan bahwa penelitian yang hampir serupa pernah dilakukan Christensen dimana dia menggunakan variabel nilai tukar yang dianggap mampu mewakili variabel kredibilitas. Penelitian tersebut menunjukkan bahwa kredibilitas bank sental bisa dinilai berdasarkan banyak hal, tetapi seringkali kredibilitas dilihat dari apa yang ditetapkan oleh bank sentral sebagai target moneternya baik itu nilai tukar, tingkat 
harga, pertumbuhan atau variabel yang lain. Ketika mampu memenuhi targetnya maka bank sentral akan disebut kredibel. Sebaliknya ketika targetnya tidak tercapai maka bank sentral akan dinilai tidak kredibel.

Mengingat sifat tidak teramati, tingkat kredibilitas umumnya berkisar antara 0 (tidak kredibel) sampai 1 (kredibel sempurna). Cecchetti dan Krause (2002) merumuskan pengukuran kredibilitas sebagai berikut:

$$
\text { IC }= \begin{cases}1 & \text { if } \pi^{\mathrm{e}} \leq \pi^{\mathrm{tar}} \\ 1-\frac{1}{0,2-\pi^{\mathrm{tar}}}\left(\pi^{\mathrm{e}}-\pi^{\mathrm{tar}}\right) \text { if } \pi^{\mathrm{tar}}<\pi^{\mathrm{e}}<20 \% \\ 0 \quad \text { if } \pi^{\wedge} \geq 20 \%\end{cases}
$$

Dengan $\Pi^{\mathrm{e}}$ adalah ekspektasi inflasi pelaku ekonomi (sektor swasta) dan $\Pi^{\text {target }}$ adalah target inflasi bank sentral. Mengacu pada rumus di atas, ketika ekspektasi inflasi sama atau melebihi batas atas 20\%, maka indeks kredibilitas akan menjadi 0 (tidak kredibel). Tidak seperti langkah-langkah sebelumnya, Cecchetti dan Krause tidak memberlakukan hukuman simetris dan di mana saja ekspektasi inflasi yang lebih rendah dari target, maka otoritas moneter dianggap sempurna kredibel.

Neuenkirch dan Tillman (2012) menyatakan bahwa ekspektasi inflasi di masa depan ditentukan dengan melihat target inflasi dan rata-rata tingkat inflasi di masa lalu.

$$
E_{t} \pi_{t+1}=\gamma_{t} \pi^{*}+\left(1-\gamma_{t}\right) \widetilde{\pi}_{t-1}
$$

Dimana $\tilde{\pi}_{\mathrm{t}-1}$ adalah rata-rata inflasi di masa lalu dan $\gamma_{\mathrm{t}}$ adalah bobot relatif terhadap target inflasi. Semakin tinggi $\gamma_{t}$, maka semakin tinggi tingkat kredibilitas bank sentral.

$$
\gamma_{t}=1-\alpha\left|\tilde{\pi}_{t-1}-\pi^{*}\right|
$$

Kredibilitas $\left(\gamma_{\mathrm{t}}\right)$ itu sendiri mencerminkan kinerja inflasi masa lalu dan dimodelkan sebagai fungsi dari deviasi absolut dari ratarata inflasi masa lalu terhadap target inflasi.

Sebagai alternatif pengukuran dari kredibilitas kebijakan moneter, Valentin dan
Rozalia (2008) menawarkan metode pengukuran kredibilitas kebijakan moneter sebagai berikut:

$$
\mathrm{ICI}_{\text {adjusted }}=\mathrm{f}(\mathrm{x})=\left\{\begin{array}{rr}
1-\frac{\left|\Pi-\Pi^{\mathrm{tar}}\right|}{\Pi^{\mathrm{tar}},}, & \mathrm{if}\left|\mathrm{II}-\Pi^{\mathrm{tar}}\right|<\Pi^{\mathrm{tar}} \\
0, & \mathrm{if}\left|\Pi-\Pi^{\mathrm{tar}}\right|>\Pi^{\mathrm{tar}}
\end{array}\right.
$$

Dengan $\Pi^{\mathrm{e}}$ adalah ekspektasi inflasi pelaku ekonomi (sektor swasta) dan $\Pi^{\text {tar }}$ adalah target inflasi bank sentral. Untuk ilustrasi, ketika ekspektasi inflasi sempurna sesuai target $\left(\Pi^{\mathrm{e}}=\Pi^{\text {tar }}\right)$, maka indeks akan mendapatkan kredibilitas 1 (atau kredibilitas yang sempurna). Sebaliknya, jika ekspektasi inflasi dua kali target inflasi atau lebih, maka indeks kredibilitas akan bernilai nol atau tidak kredibel.

Cara penghitungan kredibilitas bank sentral di atas kurang sesuai dengan pengertian kredibilitas seperti yang diungkapkan oleh Blinder, yaitu 'perbuatan yang sesuai dengan perkataan'. Untuk menyesuaikan dengan pengertian tersebut maka pengukuran kredibilitas akan di- lakukan dengan cara sebagai berikut:

$$
I C=f(x)=\left\{\begin{array}{cc}
1-\frac{\left|\pi_{t-1}-\pi^{t a r}\right|}{\pi^{t a r}}, & \text { if }\left|\pi_{t-1}-\pi^{t a r}\right|<\pi^{t a r} \\
0, & \text { if }\left|\pi_{t-1}-\pi^{t a r}\right|>\pi^{t a r}
\end{array}\right.
$$

Perbedaan persamaan tersebut jika dibandingkan dengan persamaan sebelumnya hanya pada perubahan ekspektasi inflasi $\left(\pi^{e}\right)$ menjadi inflasi $\mathrm{t}_{-1}\left(\pi_{t-1}\right)$. Perubahan ini sesuai dengan pernyataan Mankiw (2007) mengenai ekspektasi adaptif. Asumsi ini beranggapan bahwa orang-orang mengharapkan harga meningkat tahun ini pada tingkat yang sama sebagaimana tahun lalu, artinya $\pi^{e}=\pi_{t-1}$, sehingga nantinya kredibilitas akan diukur dengan membandingkan antara target inflasi dan inflasi aktual di periode sebelumnya (inflasi $i_{\mathrm{t}-1}$ )

\section{Persistensi Inflasi}

Dalam literatur, ditemui ada beberapa pengertian mengenai persistensi inflasi. Willis (2003), mendefinisikan persistensi inflasi sebagai "kecepatan kembalinya inflasi ke garis dasar atau basisnya setelah terjadi shock". Kalau diperhatikan pengertian dari 
Willis bisa diartikan bahwa persistensi inflasi itu adalah berapa lama kecepatan yang diperlukan oleh inflasi untuk kembali ke kondisi semula setelah terjadinya kejutan atau shock. Jika kecepatannya rendah bisa dikatakan bahwa inflasinya sangat persisten, akan tetapi jika kecepatannya tinggi, kita bisa mengatakan bahwa inflasinya tidak persisten. Dengan kata lain, tingkat kecepatan yang tinggi menunjukkan bahwa tingkat persistensi inflasi rendah dan sebaliknya tingkat persistensi inflasi yang tinggi ditunjukkan oleh lamanya tingkat inflasi kembali ke level ekuilibriumnya.

Gadzinski dan Orlandi (2004) mengartikan persistensi inflasi sebagai lambatnya inflasi untuk kembali pada nilai sasaran yang telah ditetapkan bank sentral ketika terjadi perubahan dalam pencapaian sasaran tersebut atau karena adanya goncangan lain. Menurut Batini (2002), terdapat tiga jenis persistensi inflasi yaitu: Pertama, serial correlation positif pada inflasi. Kedua, adanya jeda waktu antara tindakan kebijakan moneter sistematis dan pengaruhnya terhadap inflasi. Serta kelambanan respon dari inflasi terhadap kebijakan moneter tidak sistematis.

Secara harfiah, persistensi inflasi dapat diartikan sebagai keberlangsungan, atau kecenderungan untuk menguat, atau dengan istilah statistik dapat didefinisikan sebagai serial korelasi posistif. Dengan demikian, persistensi inflasi tidak hanya dapat terjadi kenaikan tetapi juga penurunan dari nilai alamiahnya. Jika posisi persistensi inflasi berada pada nilai alamiahnya, maka nilai persistensi inflasi akan bertanda positif, sedangkan jika posisi persistensi berada di bawah nilai alamiahnya, maka nilai persistensi akan bertanda negatif. Pada berbagai literatur yang ada, pembahasan persistensi inflasi kebanyakan lebih fokus pada kenaikan saja, dimana studi-studi tersebut bertujuan untuk mengetahui cepat atau lambatnya penurunan inflasi untuk dapat kembali ke nilai alamiahnya.

Marques (2004) menyatakan bahwa persistensi inflasi biasanya dibahas dalam dua pendekatan yang berbeda. Satu mendefinisikan dan mengevaluasi persistensi inflasi dalam konteks representasi univariat time-series sederhana sementara yang lain menggunakan model ekonometrik struktural yang bertujuan untuk menjelaskan perilaku inflasi. Untuk memudahkan kita bisa menyebut pendekatan yang pertama sebagai pendekatan "univariat" dan kedua sebagai pendekatan "multivariat". Persistensi biasanya dilihat mengacu pada durasi guncangan memukul inflasi. Berdasarkan pendekatan univariat model autoregressive sederhana untuk inflasi biasanya diasumsikan dan guncangan diukur dalam komponen white noise dari proses autoregressive.

Marilah kita secara singkat meninjau langkah-langkah yang paling umum digunakan dalam mengukur persistensi inflasi. Berdasarkan pendekatan univariate, persistensi diselidiki dengan melihat representasi deret waktu univariat inflasi. Alamsyah (2008) mengukur persistensi inflasi dengan mengaplikasikan persamaan univariat model AR (1) dengan bentuk persamaan sebagai berikut:

$$
\pi_{\mathrm{t}}=\mu+\alpha \pi_{\mathrm{t}-1}+\varepsilon_{\mathrm{t}}
$$

dimana $\Pi_{\mathrm{t}}$ adalah tingkat inflasi pada periode $t$, $a$ adalah koefisien otoregresif, dan $\varepsilon_{t}$ merupakan error term. Inflasi tahun ke- $t$ bergantung pada inflasi periode sebelumnya (Ajija et al., 2011). Koefisien parameter a diinterpretasikan sebagai derajat persistensi inflasi. Cara penjumlahan koefisien tersebut merupakan cara pengukuran skalar persistensi terbaik menurut Andrews dan Chen (1994). Persistensi inflasi dikatakan tinggi apabila tingkat inflasi saat ini sangat dipengaruhi oleh nilai lagnya, sehingga koefisiennya mendekati 1 . Dalam hal ini, inflasi dikatakan mendekati unit root process.

\section{Pengaruh Kredibilitas terhadap Persistensi Inflasi}

Untuk meneliti pengaruh kredibilitas bank sentral terhadap persistensi inflasi, kita tidak bisa menggunakan pendekatan univariat seperti dalam penjelasan sebelumnya. 
Pada dasarnya, pendekatan univariat tersebut hanya untuk melihat derajat persistensi inflasi saja, oleh karena itu diperlukan metode lain untuk mengukur pengaruh kredibilitas bank sentral terhadap persistensi inflasi. Metode ini sering disebut dengan pendekatan multivariat.

Selain bertujuan untuk melihat seberapa besar persistensi di Indonesia, fokus penelitian ini juga ingin melihat bagaimana pengaruh kredibilitas bank sentral terhadap persistensi inflasi itu sendiri. Penelitian ini akan menggunakan pendekatan multivariat sebagai salah satu alat analisisnya. Pendekatan multivariat sendiri memiliki banyak metode yang bisa digunakan.

New Keynesian Phillips Curve Hybrid (NKPC Hybrid) merupakan salah satu metode yang cukup populer untuk digunakan dalam melihat besarnya persistensi inflasi serta faktor-faktor yang mempengaruhinya. NKPC hybrid ini memasukkan unsur forward looking dan lagged inflation. Persamaannya dapat dituliskan sebagai berikut:

$$
\pi_{t}=\gamma_{f} E_{t}\left(\pi_{t+1}\right)+\gamma_{b} \pi_{t-1}+k y_{t}+e_{t}
$$

dimana $y$ t adalah deviasi dari output gap atau biaya marjinal (marginal cost) aktual terhadap kondisi optimal, $e_{t}$ adalah unsur kejutan dari sisi pasokan atau supply shock, $Y$ adalah koefisien pada variabel inflasi dimana terkadang direstriksi $\left(\gamma_{\mathrm{f}}+\gamma_{\mathrm{b}}\right)=1$. Untuk memperjelas restriksi tersebut, persamaannya bisa dibuat seperti di bawah ini:

$$
\pi_{t}=\alpha E_{t}\left(\pi_{t+1}\right)+(1-\alpha) \pi_{t-1}+\beta g a p_{t}+\varepsilon_{t}
$$

Ada dua metode yang bisa digunakan untuk melihat pengaruh kredibilitas terhadap persistensi inflasi. Pertama dengan membandingkan seberapa besar persistensi inflasi dalam beberapa periode dengan kredibilitas bank sentral juga dalam periode tersebut. Akan tetapi, ada metode lain yang cukup sering digunakan yaitu dengan cara memasukkan variabel kredibilitas ke dalam model, misalnya model NKPC Hybrid.
Agenor dan Taylor (1993) pernah menulis persamaan sebagai berikut:

$$
\begin{gathered}
\pi_{t}=\alpha_{t} \pi_{t-1}+\epsilon_{t} \\
\alpha_{t}=\alpha_{t-1}+\gamma C_{t}+\varepsilon_{t}
\end{gathered}
$$

Dimana $\alpha_{t}$ adalah persistensi inflasi dan $C_{t}$ adalah variabel kredibilitas. Artinya Agenor dan Taylor beranggapan bahwa persistensi inflasi dipengaruhi oleh kredibilitas. Mereka melanjutkan bahwa harusnya bernilai negatif, artinya semakin tinggi kredibilitas maka efek inersia dari inflasi atau persistensi inflasi akan semakin kecil. Agenor dan Taylor memasukkan variabel kredibilitas ke dalam model karena berpedoman pada prosedur yang pernah dilakukan oleh Christensen (1987 dan 1990). Christensen memasukkan variabel kredibilitas ke dalam model regresi. Variabel kredibilitas tersebut diukur berdasarkan kondisi nilai tukar.

Davis (2012), Napolitano dan Montaglio (2001), serta Harmanta, Bathaluddin dan Waluyo (2011) juga pernah menyatakan bahwa kredibilitas bank sentral berkorelasi secara negatif dengan persistensi inflasi. Untuk mempermudah penelitian ini maka variabel kredibilitas akan dimasukkan ke dalam model NKPC hybrid, sehingga model penelitian akan menjadi sebagai berikut:

$$
\begin{gathered}
\pi_{t}=\alpha E_{t}\left(\pi_{t+1}\right)+(1-\alpha) \pi_{t-1}+\beta g a p_{t} \\
+\gamma \operatorname{Cred}_{t}+\varepsilon_{t}
\end{gathered}
$$

Penambahan variabel tambahan dalam model NKPC hybrid ini sepertinya tidak akan menyalahi aturan karena penelitianpenelitian terdahulu juga pernah melakukan hal yang sama, contohnya penelitian yang dilakukan oleh Alamsyah (2008). Artinya model NKPC hybrid ini bisa dibilang fleksibel dan tidak hanya terpaku pada tiga variabel utama saja, yaitu inflasi periode sebelumnya, ekspektasi inflasi, dan output gap.

Dalam model NKPC hybrid, variabel dependen yang digunakan adalah inflasi aktual. Hal ini bisa jadi menimbulkan sedikit tanda tanya karena sebenarnya model 
tersebut ingin melihat pengaruh variabel independen dalam NKPC hybrid terhadap persistensi inflasi. Penjelasannya bisa kita dapatkan dari kerangka fikir di atas. Pertama akan dilihat nilai persistensi inflasi berdasarkan nilai koefisien AR, kemudian tentukan apakah koefisien tersebut signifikan atau tidak (berdasar nilai probabilitas). Ketika nilai probabilitas menunjukkan nilai yang signifikan maka artinya perubahan nilai inflasi aktual juga menandakan akan berubahnya nilai persistensi inflasi (koefisien AR). Singkat kata, perubahan inflasi aktual mencerminkan perubahan nilai persistensi inflasi, sehingga hal ini memungkinkan kita untuk menggunakan inflasi aktual sebagai variabel dependen dalam model NKPC hybrid.

\section{METODE PENELITIAN}

\section{Jenis Penelitian}

Penelitian ini disusun dengan pendekatan positivis. Data yang digunakan berupa data sekunder yang berasal dari Bank Indonesia. Data tersebut nantinya akan diolah supaya nantinya bisa memberikan jawaban terhadap rumusan masalah yang diangkat dalam penelitian ini.

\section{Jenis dan Sumber Data}

Data yang akan digunakan dalam penelitian ini berupa data sekunder yang meliputi: Pertama, inflasi Triwulanan (yearon-year) tahun 2000-2012. Sumber data berasal dari Bank Indonesia. Kedua, target Inflasi dari tahun 2000-2012. Sumber data berasal dari Bank Indonesia. Ketiga, GDP triwulanan dari tahun 2000-2012. Sumber data berasal dari Bank Indonesia. Terakhir, ekspektasi inflasi triwulanan tahun 20002012. Sumber data berasal dari hasil survey yang dilakukan Bank Indonesia.

Latar belakang penggunaan data inflasi year-on-year berdasarkan beberapa alasan. Penggunaan data inflasi month-on-month ataupun quarter-to-quarter sangat terkait dengan faktor seasonal sehingga dikhawatirkan kurang dapat menggambarkan tingkat persistensi inflasi yang sebenarnya (Arimurti, 2011).

\section{Teknik Analisis Data}

\section{a. Uji Stasioneritas Data}

Dalam ekonometrika, data yang akan digunakan harus stasioner khususnya untuk data time series. Secara statistik, sebuah data time series dikatakan stasioner jika rata-rata dan varians data tersebut konstan dari waktu ke waktu dan nilai kovarian diantara dua periode bergantung hanya pada jarak atau kelambanan antara dua periode waktu tersebut, bukan tergantung pada waktu sesungguhnya saat dihitungnya kovarian. Selain itu adanya data yang terlalu besar selama periode pengamatan dan mempunyai kecenderungan untuk mendekati nilai rata-ratanya (Engle dan Granger, 1987).

Dengan mendefinisikan random walks sebagai perilaku series yang bervariasi terhadap perubahan waktu dan tidak mempunyai batas variance yang tetap, maka pengujian random walks adalah pengujian stationarity. Jika variabel terbukti non stasioner, maka dengan berjalannya waktu maka variabel tersebut cenderung untuk tidak kembali pada suatu kecenderungan jangka panjang yang sama (random walks). Sebaliknya jika variabel ternyata stasioner, maka dengan berjalannya waktu variabel tersebut akan cenderung kembali pada suatu kecenderungan jangka panjang yang tetap.

Uji yang paling sering digunakan untuk melihat stasioneritas data adalah Dickey Fuller-Test (DF-Test) yang kemudian berkembangkan menjadi Augmented Dickey Fuller-Test (ADF-Test). Metode ini banyak mendapat kritikan karena penggunaannya menuntut sampel data yang besar. Selain itu, metode ini juga sangat sering menerima hipotesa null bahwa data tidaklah stasioner (Gujarati, 2003).

\section{b. Chow Test}

Dalam mengestimasi model yang menggunakan data time series, dimungkinkan munculnya perubahan struktural (structural break). Akan tetapi, ada juga yang 
menyebutnya dengan structural shift atau jump (Ariefianto, 2012). Oleh karena perubahan struktural ini, maka bisa diartikan bahwa nilai parameter dari model tidak sama sepanjang periodenya (Gujarati dan Porter, 2010). Perubahan struktural bisa terjadi karena kekuatan eksternal, perubahan kebijakan, tindakan pemerintah, maupun penyebab lainnya (Gujarati, 2003). Pola hubungan suatu variabel dengan variabel lain sangat mungkin berbeda antara satu periode dengan periode lainnya. Untuk mengetahui stabilitas parameter dari suatu persamaan dalam satu seri data runtut waktu dapat digunakan chow test. Uji ini pertama kali dikemukan oleh Chow (1960).

Salah satu metode yang dapat digunakan dalam chow test adalah chow's breakpoint test. Metode ini memiliki tujuan untuk mencocokkan persamaan secara terpisah untuk setiap sub sampel dan melihat apakah terdapat perbedaan yang signifikan dalam persamaan yang diestimasi (Anonim, 2004).

\section{c. Autoregressive (AR)}

Seperti yang dijelaskan sebelumnya, ada beberapa metode yang dapat digunakan untuk mengukur derajat persistensi inflasi pada pendekatan univariat. Dengan melihat kelebihan dan kekurangan masing-masing, penelitian ini akan menggunakan metode autoregressive (AR) sebagai berikut:

$$
\pi_{\mathrm{t}}=\mu+\alpha \pi_{\mathrm{t}-1}+\varepsilon_{\mathrm{t}}
$$

Dari hasil estimasi persamaan tersebut, tingkat persistensi inflasi dihitung dengan melihat jumlah koefisien AR. Ini merupakan cara pengukuran skalar persistensi terbaik menurut Andrews dan Chen (1994).

\section{d. Estimasi Model NKPC Hybrid}

Berdasarkan penjelasan-penjelasan sebelumnya, model NKPC hybrid yang akan diestimasi adalah sebagai berikut:

$$
\begin{gathered}
\pi_{t}=\alpha E_{t}\left(\pi_{t+1}\right)+(1-\alpha) \pi_{t-1}+\beta g a p_{t}+ \\
\gamma \operatorname{Cred}_{t}+\varepsilon_{t}
\end{gathered}
$$

Dimana:

$\Pi_{\mathrm{t}} \quad=$ tingkat inflasi pada waktu $\mathrm{t}$

$\mathrm{E}_{\mathrm{t}}\left(\Pi_{\mathrm{t}+1}\right) \quad=$ ekspektasi inflasi

$\Pi_{\mathrm{t}-1} \quad=$ inflasi periode sebelumnya

gap $_{t} \quad=$ output gap

Cred $_{\mathrm{t}}=$ kredibilitas bank sentral

Model NKPC hybrid ini nantinya akan diestimasi dengan menggunakan metode Ordinary Least Square. Persisten atau tidaknya inflasi di Indonesia bisa dilihat penyebabnya dengan mengestimasi model NKPC hybrid tersebut.

\section{ANALISIS DAN PEMBAHASAN}

Uji Stasioneritas dan Chow Breakpoint Test

Dalam melakukan uji stasioneritas, kita harus memperhatikan nilai probabilitas. Jika nilai probabilitas berada di bawah $\alpha=1 \%, \alpha=$ $5 \%$, ataupun $\alpha=10 \%$, maka tidak terjadi unit root. Sebaliknya, jika nilai probabilitas lebih besar dari $\alpha=1 \%, \alpha=5 \%$, ataupun $\alpha=10 \%$, maka itu menandakan terjadinya unit root. Selain itu, kita juga bisa membandingkan nilai t-statistik dan nilai kritis untuk menentukan apakah hipotesis null adanya unit root dapat ditolak atau tidak.

Tabel 1

\section{Uji Stasioneritas Data Inflasi}

\begin{tabular}{lccc}
\hline \hline Null Hypothesis: INFLASI has a unit root & & \\
Exogenous: Constant \\
Lag Length: 1 (Automatic based on SIC, MAXLAG=10) & & \\
\hline \multicolumn{2}{l}{-Statistic } & Prob. $^{*}$ \\
\hline Augmented Dickey-Fuller test statistic & & -3.781404 & 0.0056 \\
\hline Test critical values: & $1 \%$ level & -3.571310 & \\
& $5 \%$ level & -2.922449 & \\
& $10 \%$ level & -2.599224 & \\
\hline
\end{tabular}

Sumber: Data diolah 
Dari hasil uji stasioneritas di tabel 1 bisa kita lihat bahwa nilai probabilitas adalah 0,0056 atau lebih kecil jika dibandingkan dengan $\alpha$. Dimana artinya variabel inflasi sudah stasioner pada $\alpha=1 \%, \alpha=5 \%$, ataupun $\alpha=10 \%$. Hasil perbandingan antara nilai t-statistik dan nilai kritis menunjukkan hal serupa. Nilai t-statistik lebih kecil daripada nilai kritis baik pada $\alpha=1 \%, \alpha=5 \%$, ataupun $\alpha=10 \%$. Artinya, hipotesis null adanya unit root bisa ditolak.
Selanjutnya akan dilakukan chow test untuk melihat kemungkinan terjadinya perubahan struktural (structural break). Uji ini bisa dilakukan dengan membandingkan nilai F-statistik dan probabilitasnya. Ketika nilai F-statistik lebih besar daripada nilai probabilitasnya maka itu sudah menunjukkan adanya structural break dalam suatu periode.

Tabel 2

Chow Breakpoint Test

\begin{tabular}{lcll}
\hline \hline Chow Breakpoint Test: $2006: 1$ & & \\
\hline F-statistic & 1.227840 & robability & 0.302550 \\
Log likelihood ratio & 2.603555 & robability & 0.272048 \\
\hline
\end{tabular}

Sumber: Data diolah

Berdasarkan perkiraan awal, diprediksi bahwa akan terjadi structural break pada tahun 2005 tepatnya pada kuarter ketiga (2005:3). Alasannya karena pada saat itulah Bank Indonesia mulai menerapkan ITF secara penuh, yaitu full-fledged inflation targeting, setelah sebelumnya menerapkan inflation targeting. Ternyata perkiraan terjadinya structural break pada tahun 2005 kuarter ketiga tidak sepenuhnya benar. Sebenarnya perkiraan tersebut juga tidak sepenuhnya salah karena structural break masih terjadi pada periode di sekitar tahun 2005 kuarter ketiga, yaitu pada tahun 2006 kuarter pertama (2006:1). Hal ini dikarenakan nilai F-statistik yang lebih tinggi daripada nilai probabilitas pada periode tersebut, yaitu 1.227840 berbanding 0.302550. Dari hasil chow test ini, nantinya data akan dibagi menjadi dua periode, yaitu
2000:1-2005:4 dan 2006:1-2012:3. Periode pertama (2000:1-2005:4) adalah periode inflation targeting lite. Sedangkan periode kedua (2006:1-2012:3) akan dinamakan periode full-fledged inflation targeting.

\section{Estimasi Model Autoregressive (AR)}

Setelah diketahui ketepatan waktu munculnya structural break yang diperoleh melalui hasil chow breakpoint test dan telah dipastikan pula bahwa variabel memang stasioner, maka selanjutnya dapat dilakukan estimasi model autoregressive. Karena estimasi yang digunakan adalah model autoregressive, maka ukuran persistensi inflasi adalah nilai dari koefisien autoregressive.

Hasil estimasi model autoregressive pada periode inflation targeting lite menunjukkan bahwa persistensi inflasi adalah sebesar 0.468957 .

Tabel 3

Hasil estimasi model Autoregressive (AR)

\begin{tabular}{lc}
\hline \multicolumn{1}{c}{ Periode } & Persistensi Inflasi \\
\hline Inflation Targeting Lite & 0.468957 \\
Full-Fledged Inflation Targeting & 0.378881 \\
\hline
\end{tabular}


Koefisien ini tidak jauh berbeda dengan hasil estimasi full sample sehingga kembali bisa disimpulkan bahwa selama periode 2000:1-2005:4 inflasi tidaklah persisten.

Untuk periode full-fledged inflation targeting, hasil estimasi model autoregressive menunjukkan persistensi inflasi sebesar 0.378881 . Koefisien ini sedikit lebih rendah di bandingkan dengan periode sebelumnya. Akan tetapi, selama periode 2006:1-2012:3 inflasi bisa dikatakan tidak persisten.

Hasil estimasi ini berbeda dari perkiraan sebelumnya dimana diperkirakan persistensi inflasi di Indonesia masih relatif tinggi, kenyataannya tidaklah demikian Persistensi inflasi di Indonesia relatif cukup rendah. Persistensi inflasi di Indonesia cenderung mengalami penurunan pada periode fullfledged inflation targeting jika dibandingkan dengan periode inflation targeting lite.

\section{Estimasi Model NKPC Hybrid}

a. Estimasi Model NKPC Hybrid Periode Inflation Targeting Lite

Hasil estimasi untuk periode inflation targeting lite (2000:2-2005:4) adalah sebagai berikut:

Tabel 4

Estimasi Model NKPC Hybrid Periode 2000:2-2005:4

\begin{tabular}{lcc}
\hline \multicolumn{1}{c}{ Variabel } & Koefisien & Probabilitas \\
\hline Ekspektasi Inflasi & 0.2599116 & 0.165 \\
Inflasi $\mathrm{t}_{\mathrm{t}-\mathrm{i}}$ & 0.7400884 & 0.001 \\
Output Gap & 19.45755 & 0.032 \\
Kredibilitas & 0.5891048 & 0.794 \\
Konstanta & 0.0929179 & 0.959 \\
\hline
\end{tabular}

Sumber : Data diolah

Berdasarkan tabel 4, kita bisa melihat bahwa variabel yang berpengaruh terhadap persistensi inflasi yaitu Inflasi $i_{t-1}$ dan Output Gap Sementara itu, kredibilitas tidaklah demikian.

\section{b. Estimasi Model NKPC Hybrid Periode Full-FledgedInflation Targeting}

Periode full-fledged inflation targeting adalah tahun 2006:1-2012:3. Hasil estimasi untuk periode kedua tersebut adalah sebagai berikut:

Tabel 5

Uji Multikolinearitas

\begin{tabular}{cccrr}
\hline & Kredibilitas & $\begin{array}{c}\text { Ekspektasi } \\
\text { Inflasi }\end{array}$ & Output Gap & Inflasi $_{\mathrm{t}-1}$ \\
\hline \hline Kredibilitas & 1.000000 & -0.602701 & -0.225128 & -0.779655 \\
Ekspektasi Inflasi & -0.602701 & 1.000000 & 0.027800 & 0.878200 \\
Output Gap & -0.225128 & 0.027800 & 1.000000 & 0.084294 \\
$\quad$ Inflasit-1 & -0.779655 & 0.878200 & 0.084294 & 1.000000 \\
\hline Sumber Data diolah & & & &
\end{tabular}

Dari hasil uji ternyata terjadi multikolinearitas antara variabel ekspektasi inflasi dan inflasi $\mathrm{t}_{\mathrm{t}-1}$. Nilai koefisien korelasi keduanya adalah sebesar 0.878200 . Berdasar- kan beberapa pertimbangan, inflasi $\mathrm{t}_{\mathrm{t}-1}$ akan dikeluarkan dari model. Artinya variabel yang tersisa hanya ekspektasi inflasi, output gap, dan kredibilitas. 
Tabel 6

Estimasi Model NKPC Hybrid Periode 2006:1-2012:3

\begin{tabular}{lcc}
\hline \multicolumn{1}{c}{ Variabel } & Koefisien & Probabilitas \\
\hline Ekspektasi Inflasi & 1.749770 & 0.0001 \\
Output Gap & 14.66898 & 0.2512 \\
Kredibilitas & -2.562097 & 0.0462 \\
Konstanta & -4.260172 & 0.2056 \\
\hline
\end{tabular}

Sumber : Data diolah

Untuk mempersingkat hasil-hasil estimasi model NKPC Hybrid untuk periode inflation targeting lite dan full-fledged inflation targeting, kita bisa memperhatikan tabel di bawah ini. Dari tabel 6 kita bisa melihat nilai koefisien setiap variabel, nilai probabilitas, dan apakah variabel berpengaruh atau tidak terhadap persistensi inflasi.

Tabel 7

Hasil Estimasi Model NKPC Hybrid

\begin{tabular}{lcccccc}
\hline \hline \multirow{2}{*}{ Variabel } & \multicolumn{3}{c}{ Inflation Targeting Lite } & \multicolumn{3}{c}{ Full-Fledged Inflation Targeting } \\
\cline { 2 - 7 } & Koefisien & Prob. & Pengaruh & Koefisien & Prob. & Pengaruh \\
\hline Ekspektasi & 0.2599116 & 0.165 & Tidak & 1.749770 & 0.0001 & Ada \\
Inflasit -1 & 0.7400884 & 0.001 & Ada & - & - & - \\
Output Gap & 19.45755 & 0.032 & Ada & 14.66898 & 0.2512 & Tidak \\
Kredibilitas & 0.5891048 & 0.794 & Tidak & -2.562097 & 0.0462 & Ada \\
Kostanta & 0.0929179 & 0.959 & - & -4.260172 & 0.2056 & - \\
\hline
\end{tabular}

Sumber: Data diolah

Setiap variabel bisa ditentukan apakah berpengaruh atau tidak terhadap persistensi inflasi, yaitu dengan membandingkan antara nilai adengan nilai probabilitas. Jika nilai probabilitas kurang dari $\alpha$ maka variabel tersebut memiliki pengaruh terhadap persistensi inflasi. Dari tabel 7 bisa dilihat bahwa pada periode inflation targeting lite hanya variabel inflasi $\mathrm{i}_{\mathrm{t}-1}$ dan output gap yang mempengaruhi persistensi inflasi. Sementara pada periode full-fledged inflation targeting, ekspektasi inflasi dan kredibilitas lebih berpengaruh terhadap persistensi inflasi. Hal ini bisa diartikan bahwa pelaku ekonomi di Indonesia ternyata lebih cenderung berperilaku backward looking pada periode inflation targeting lite, sedangkan pada periode full-fledged inflation targeting, pelaku ekonomi di Indonesia mulai berperilaku forward looking. Sementara itu, kredibilitas ternyata tidak berpengaruh terhadap persistensi inflasi selama periode inflation targeting lite, tetapi pada periode full-fledged inflation targeting, hal sebaliknyalah yang terjadi. Hal ini merupakan pengaruh positif perubahan kerangka kebijakan bank Indonesia, inflation targeting lite menjadi full-fledged inflation targeting.

\section{Pembahasan}

\section{a. Periode Inflation Targeting Lite}

Secara garis besar, hasil penelitian menunjukkan bahwa persistensi inflasi di Indonesia masih cukup rendah. Ini bertentangan dengan hasil penelitian Alamsyah (2008) yang menyatakan persistensi inflasi di Indonesia masih cukup tinggi. Selain itu, pelaku ekonomi di Indonesia ternyata lebih cenderung berperilaku backward looking. Hal ini dikarenakan variabel inflasit-1 yang pengaruhnya terlihat dominan sebagai sumber persistensi inflasi terutama pada periode inflation targeting lite. Pendapat bahwa pelaku ekonomi di Indonesia lebih cenderung berperilaku backward looking pada periode inflation targeting lite ini juga pernah 
diungkapkan oleh Alamsyah (2008). Selain itu, diketahui pula bahwa ternyata kredibilitas bank sentral tidak berpengaruh terhadap persistensi inflasi. Hasil penelitian ini tentunya bertentangan dengan hasil penelitian Harmanta et al (2011), Davis (2012) serta banyak penelitian lain yang menyatakan kredibilitas sangat menentukan tingkat persistensi inflasi.

Periode inflation targeting lite merupakan tahapan awal bank sentral untuk mulai menggunakan kerangka kebijakan ITF. Setelah krisis tahun 1998 dan berbagai macam hal yang menyertai, tentu tidak mudah bagi masyarakat untuk mempercayai bahwa bank sentral mampu dan berkomitmen untuk mencapai target inflasi yang telah ditetapkan. Artinya periode inflation targeting lite termasuk masa yang sulit bagi bank sentral. Setiap kebijakan yang diambil cenderung belum banyak mendapat respon yang positif dari masyarakat, mengingat kredibilitas bank sentral yang belum cukup baik di mata masyarakat. Dengan kata lain, cukup masuk akal jika kredibilitas bank sentral belum banyak memberi pengaruh dalam upaya mengontrol laju inflasi, sehingga pada akhirnya inflasi menjadi lebih persisten.

Tingginya inflasi IHK tidak terlepas dari pengaruh ekspektasi inflasi produsen dan pedagang, serta konsumen. Berdasarkan Survei Mekanisme Pembentukan Harga di Sektor Manufaktur dan Ritel (Bank Indonesia, 2001), diketahui bahwa dasar pembentukan ekspektasi inflasi pada produsen dan pedagang ritel lebih banyak bersumber dari perkembangan inflasi aktual dan inflasi tahun sebelumnya. Survei ini dilakukan Bank Indonesia pada tahun 2001, kurang lebih pada awal periode inflation targeting lite. Hal ini sebenarnya bisa menjadi bukti terhadap perilaku masyarakat yang backward looking. Pelaku ekonomi yang kurang mengacu pada target inflasi Bank Indonesia menunjukkan kurang kredibelnya Bank Indonesia di mata mereka. Pelaku ekonomi tidak yakin sepenuhnya bahwa Bank Indonesia mampu mencapai target tersebut, sehingga pada akhirnya pelaku ekonomi cenderung mengacu pada inflasi aktual pada periode sebelumnya dalam pembentukan ekspektasi inflasi.

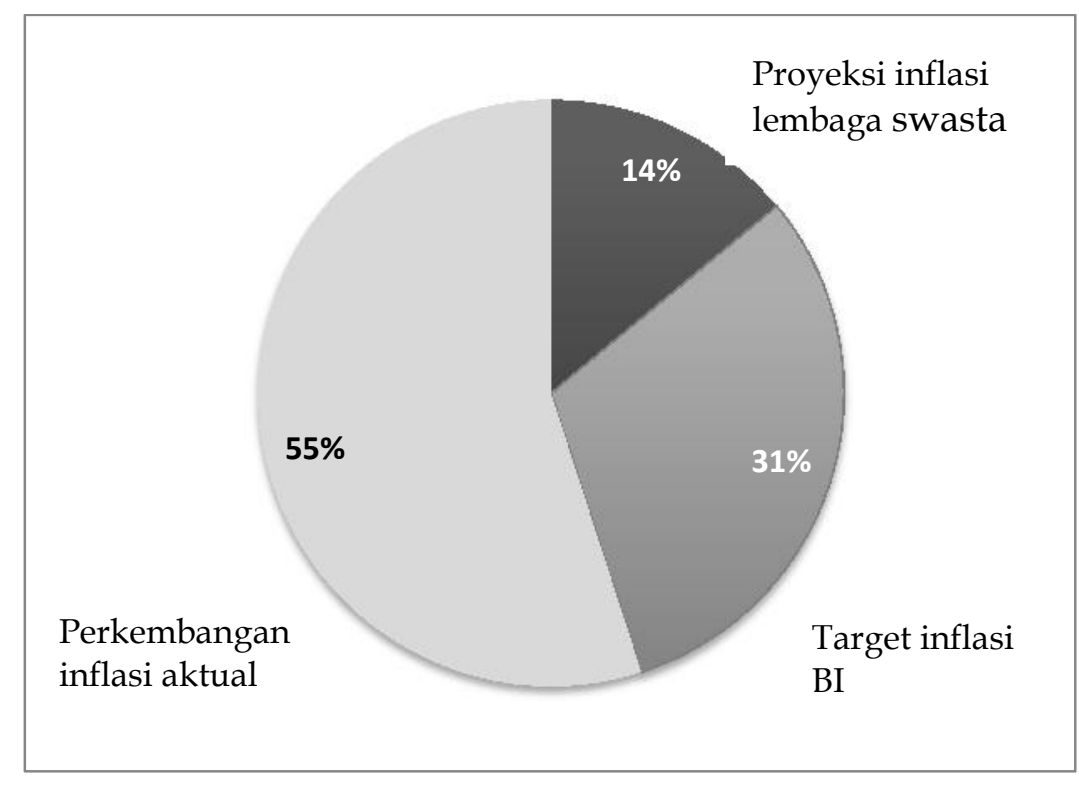

Gambar 1

Acuan dalam Pembentukan Ekspektasi Inflasi Produsen (\% Responden) 


\section{b. Periode Full-Fledged Inflation Targeting}

Pada periode full-fledged inflation targeting, ternyata persistensi inflasi cenderung menurun dibandingkan dengan periode inflation targeting lite. Hasil estimasi NKPC hybrid menunjukkan hasil yang jauh berbeda dengan periode inflation targeting lite. Ekspektasi inflasi dan kredibilitas sangat berpengaruh terhadap persistensi inflasi. Hal ini menunjukkan pelaku ekonomi di Indonesia mulai berperilaku forward looking. Pendapat yang serupa bahwa pelaku ekonomi di Indonesia lebih cenderung berperilaku forward looking pada periode full-fledged inflation targeting ini juga pernah diungkapkan oleh Harmanta et al (2011) dan Hutabarat (2005). Perubahan perilaku ini bisa jadi ada kaitannya dengan perubahan rezim dari inflation targeting lite menjadi full-fledged inflation targeting. Artinya perubahan kerangka kebijakan dari inflation targeting lite menjadi full-fledged inflation targeting memberikan pengaruh yang cukup baik dimana pelaku ekonomi tidak berperilaku backward looking lagi dan lebih condong berperilaku forward looking. Perubahan perilaku tersebut bisa dibilang baik karena berdasarkan banyak penelitian diketahui perilaku forward looking akan berakibat terkendalinya laju inflasi atau inflasi menjadi tidak persisten.

Tentu juga menjadi bahasan yang cukup menarik bagaimana bank sentral bisa membuat kredibilitas mereka mampu mempengaruhi persistensi inflasi selama periode full-fledged inflation targeting. Hasil penelitian ini tentunya sangat mendukung hasil penelitian Harmanta et al (2011) dan Davis (2012) yang menyatakan kredibilitas sangat menentukan tingkat persistensi inflasi. Padahal sebelum periode tersebut, tepatnya tahun 2005, kredibilitas bank sentral sempat jatuh. Hal ini dikarenakan naiknya harga BBM sehingga harga-harga cenderung tidak terkendali. Sementara itu, pada tahun 2008 terjadi krisis global yang tentunya membuat bank sentral cukup kesulitan dalam mengontrol laju inflasi selama periode fullfledged inflation targeting.
Fakta berpengaruhnya kredibilitas bank sentral terhadap persistensi inflasi selama periode full-fledged inflation targeting tentu menarik untuk ditelusuri alasannya. Semuanya tentu terkait dengan respon yang baik dari bank sentral untuk mengatasi setiap masalah yang melanda selama menerapkan full-fledged inflation targeting. Banyak keputusan penting yang diambil oleh bank sentral sehingga kredibilitas mereka cenderung membaik dibandingkan dengan periode inflation targeting lite.

Berbagai macam upaya positif yang telah dilakukan Bank Indonesia dalam mengatasi setiap permasalahan yang melanda, sepertinya bisa menjadi alasan kuat dibalik meningkatnya kredibilitas mereka di mata masyarakat. Tentu tidak mengherankan ketika persistensi inflasi mengalami penurunan sebagai akibat dari meningkatnya kredibilitas Bank Indonesia selama periode full-fledged inflation targeting, sehingga pada akhirnya laju inflasi cenderung lebih mudah untuk dikontrol. Bank sentral mampu meyakinkan banyak pihak jika mereka memang memiliki komitmen kuat untuk mongontrol laju inflasi agar sesuai dengan apa yang telah ditargetkan. Komitmen yang kuat dalam mengontrol laju inflasi ini pada akhirnya akan membuat bank sentral menjadi sangat kredibel di mata masyarakat, sehingga kredibilitas bank sentral ini mampu membuat laju inflasi menjadi tidak persisten.

Hal tersebut menunjukkan pentingnya kredibilitas bagi sebuah bank sentral yang menerapkan inflation targeting framework (ITF). Menurut Pohan (2008), kerangka konstitusional adalah prasyarat penting yang mutlak diperlukan oleh bank sentral dalam menerapkan ITF. Kerangka operasionalnya pada umumnya antara lain terdiri atas beberapa hal berikut, yaitu mandat, independensi, transparansi dan akuntabilitas. Hal-hal tersebut dirasa cukup krusial perannya untuk menjaga kredibilitas bank sentral.

Karakteristik utama kerangka kebijakan ITF adalah adanya suatu mandat yang 
menetapkan target inflasi sebagai tujuan utama kebijakan moneter. Dengan kata lain, target seperti pertumbuhan atau tingkat pengangguran harus diletakkan sebagai sasaran yang perioritasnya masih di bawah pencapaian target inflasi. Mandat tersebut merupakan karakteristik utama dalam membedakan antara bank sentral yang menerapkan ITF dengan bank yang hanya mengumumkan proyeksi inflasi.

Dalam penerapan ITF, penting bagi bank sentral untuk memiliki target dan instrumen yang sifatnya independen. Untuk dapat melaksanakan mandat kebijakan moneter yang efektif, bank sentral memerlukan independensi dalam pemilihan dan penggunaan instrumen moneter. Independensi ini penting untuk menjaga kredibilitas bank sentral. Sebisa mungkin akan lebih baik jika tidak ada campur tangan dari luar dalam pemilihan dan penggunaan instrumen moneter tersebut.

Selain diperlukan adanya pemilihan dan penggunaan instrumen secara independen, proses pengambilan kebijakan bank sentral harus bersifat transparan dan memiliki akuntabilitas. Dalam penerapan ITF, bank sentral dituntut untuk bekerja secara transparan mengingat akuntabilitas merupakan kunci keberhasilan ITF. Sebagai implikasi dari pemberian mandat dan adanya independensi dalam mencapai tujuan ITF, maka bank sentral dituntut untuk dapat mempertanggungjawabkan kebijakan yang telah dilakukan dalam upaya pencapaian target inflasi (accountable). Penjelasan bank sentral secara transparan tentang kebijakan moneternya akan memberi insentif dalam pencapaian target inflasi melalui peningkatan kepercayaan publik.

\section{SIMPULAN DAN SARAN Simpulan}

Selama menerapkan Inflation Targeting Framework (ITF) persistensi inflasi di Indonesia tidak bisa dibilang tinggi. Artinya inflasi cenderung tidak persisten. Hasil estimasi ini berbeda dari yang diperkirakan sebelumnya. Hipotesis penelitian memper- kirakan persistensi inflasi di Indonesia masih relatif tinggi. Ternyata pada kenyataannya tidaklah demikian, tetapi persistensi inflasi di Indonesia cenderung mengalami penurunan pada periode full-fledged inflation targeting jika dibandingkan dengan periode inflation targeting lite.

Pada periode inflation targeting lite, kredibilitas tidak berpengaruh terhadap persistensi inflasi. Hal ini bisa jadi disebabkan oleh perilaku para pelaku ekonomi di Indonesia yang ternyata lebih cenderung berperilaku backward looking. Hal ini dikarenakan variabel inflasi $\mathrm{t}_{-1}$ yang pengaruhnya terlihat dominan sebagai sumber persistensi inflasi terutama pada masa inflation targeting lite. Sementara itu, pada periode full-fledged inflation targeting, ternyata hasil estimasi menunjukkan hasil yang jauh berbeda dengan periode inflation targeting lite. Kredibilitas sangat berpengaruh terhadap persistensi inflasi. Hal ini sebagai akibat dari pelaku ekonomi di Indonesia yang mulai berperilaku forward looking.

\section{Saran}

Hasil penelitian menunjukkan bahwa perubahan kerangka kebijakan dari inflation targeting lite menjadi full-fledged inflation targeting memberikan pengaruh yang cukup baik dimana pelaku ekonomi tidak berperilaku backward looking lagi dan lebih condong berperilaku forward looking. Selain itu, kredibilitas bank sentral juga berpengaruh terhadap persistensi inflasi terutama pada periode full-fledged inflation targeting. Tentunya saran yang akan diberikan tidak jauh dari hasil penelitian tersebut.

Bank sentral harus terus meningkatkan kredibilitasnya atau setidaknya mempertahankan kredibilitas mereka di mata masyarakat atau pun para pelaku ekonomi Indonesia. Tujuannya agar mereka mau merespon dengan baik setiap kebijakan yang akan diambil oleh bank sentral. Ketika kredibilitas bank sentral cenderung menurun secara drastis, tentu hal ini bisa menjadi bumerang bagi bank sentral sendiri. 
Setiap kebijakan atau arahan yang dilakukan bank sentral tidak akan mendapat respon dengan baik. Hal semacam ini bisa menjadi persoalan yang pelik terutama ketika Indonesia sedang dilanda masalah dalam perekonomiannya. Masalah tersebut akan menjadi berlarut-larut dan cenderung sulit mencari solusi sebagai penyelesaian masalah. Hal sebaliknya akan terjadi jika bank sentral mampu menjaga kredibilitasnya.

Pengaruh ekspektasi inflasi cukup besar terhadap tingkat persistensi inflasi di Indonesia terutama pada periode full-fledged inflation targeting. Hal ini tentu bisa dibilang pencapaian yang baik dari bank sental. Bank sentral harus mampu mengarahkan ekpektasi masyarakat dan pelaku ekonomi agar bisa merespon setiap kebijakan yang diambil bank sentral. Sehingga nantinya ekpektasi inflasi masyarakat dan pelaku ekonomi bisa mendekati proyeksi atau target inflasi yang telah ditetapkan bank sentral. Akibatnya tentu inflasi akan cenderung lebih tidak persisten dan pada akhirnya inflasi akan lebih mudah untuk dikontrol perkembangannya.

\section{DAFTAR PUSTAKA}

Agenor, Pierre-Richard and M. P. Taylor. 1993. Analysing Credibility in HighInflation Countries: A New Approach. The Economic Journal 103: 329-336.

Ajija, S.R., D. W. Sari., R. H. Setianto, dan M. R. Primanti. 2011. Cara Cerdas Menguasai Eviews. Salemba Empat. Jakarta.

Alamsyah, Halim. 2008. Persistensi Inflasi dan Dampaknya Terhadap Pilihan dan Respon Kebijakan Moneter di Indonesia. Disertasi. Program Pascasarjana Universitas Indonesia. Depok.

Andrews, D.W.K, dan H.Y. Chen. 1994. Approximately Median-Unbiased Estimation of Autoregressive Models. Journal of Business \& Economic Statistics 12(2).

Anonim. 2004. Eviews 5 User's Guide. Quantitative Micro Software, LLC, United States of America.
Aoki, K. dan T. Kimura. 2006. Learning About Belief About Inflation Target and Stabilisation Policy. Prosiding London School of Economics: 1-27.

Ariefianto, M. D. 2012. Ekonometrika, Esensi dan Aplikasi dengan Menggunakan Eviews. Erlangga. Jakarta.

Arimurti, T. dan B. Trisnanto.2011. Persistensi Inflasi di Jakarta dan Implikasinya Terhadap Kebijakan Pengendalian Inflasi Daerah. Buletin Ekonomi Moneter dan Perbankan 14(1): 5-29.

Bank Indonesia. 2012. Inflasi. www.bi.go.id. Diakses tanggal 20 Oktober 2012.

Batini, Nicoletta. 2002. Euro Area Inflation Persisten. Europan Central Bank Working Paper 201: 1-59.

Cechetti, S. G. and S. Krause. 2002. Central Bank Structure, Policy Efficiency, and Macroeconomics Performance: Exploring Empirical Relationships. Prosiding The Federal Reserve Bank of St. Louis: 4760.

Chow, G. C. 1960. Test of Equality Between Sets of Coefficients in Two Linier Regressions. Econometrica 28(3): 591-605.

Davis, J. S. 2012. Central Bank Credibility and the Persistence of Inflation and Inflation Expectations. Federal Reserve Bank of Dallas, Globalization and Monetary Institute Working Paper 117: 1-42.

Engle, Robert F. dan C. W. J. Granger. 1987. Co-Integration and Error Correction: Representation, Estimation and Testing. Econometrica 55(2): 251-276.

Erceg, C. J., and A. T. Levin. 2003. Imperfect Credibility and Inflation Persistence. Journal of Monetary Economics 50: 915944.

Garcia, A. J. 2000. Essays in Credibility and The Source of Persistence inflation. Disertasi. Departement of Economics University of Warwick.

Ghezzi, P. 2001. Backward-looking indexation, Credibility and Inflation Persistence. Journal of International Economics 53: 127-147.

Giavazzi, F. and M. Pagano. 1988. The Advantage of Tying One's Hands: EMS 
Discipline and Central Bank Credibility. European Economic Review 32(5): 10551075.

Gonzalez G. Andre and F. Hamann. 2011. Lack of Credibility, Inflation Persistence and Disinflation in Colombia. Banco de la Republica, Colombia, Primer Semestre de 2011: 61-97.

Gujarati, D. N. 2003. Basic Economterics. $4^{\text {th }}$ Edition. McGraw-Hill. New York.

Gujarati, D. N dan D. Porter. 2010. Dasardasar ekonometrika. Buku 1 Edisi 5. Salemba Empat. Jakarta.

Harmanta, M. B. Bathaludin, dan J. Waluyo. 2011. Inflation Targeting Under Imperfect Credibility: Lessons from Indonesian Experience. Bulletin of Monetary, Economics and Banking 2011: 271-306.

Hutabarat, A. R. 2005. Determinan Inflasi Indonesia. Bank Indonesia Occasional Paper 6: 1-39.

Mankiw, N. G. 2007. Makroekonomi. Edisi Keenam. Erlangga. Jakarta.

Marques, C. R. 2004. Inflation Persistence, Facts or Artefacts? European Central Bank, Working Paper Series 371: 1-50.

Napolitano, O. and A. Montagnoli. 2001. Inflation Persistence and Credibility in Turkey during The Nineties. Prosiding
International Conference in Economics $V$ Ankara: 1-19.

Neuenkirch, M. and P. Tillmann. 2012. Inflation Targeting, Credibility, and Non-Linear Taylor Rules. Joint Discussion Paper Series in Economics 35: 1-15.

Pohan, A. 2008. Kerangka Kebijakan Moneter \& Implementasinya di Indonesia. PT. Raja Grafindo Persada. Jakarta.

Pohan, A. 2008. Potret Kebijakan Moneter Indonesia Seberapa Jauh Kebijakan Moneter Mewarnai Perekonomian Indonesia. PT. Raja Grafindo Persada. Jakarta.

Sargent, T. (1999). The conquest of American inflation. Princeton University press. Princeton.

Svensson, Lars E.O. 1999. Inflation Targeting as a Monetary Policy Rule. Journal of Monetary Economics: 43(3): 607-54.

Valentin, T and R.V. Rozalia. 2008. Evaluation Of National Bank Of Romania Monetary Policy Credibility. Prosiding Babes-Bolyai University, Faculty of Business, Cluj Napoca: 497-502.

Willis, J. L. 2003. Implications of structural changes in the U.S. economy for pricing behavior and inflation dynamics. Federal Reserve Bank of Kansas City Economic Review 88(1): 5-27. 